\title{
Effect of Plant Growth Regulators on Growth of Grape Rootstock
}

\author{
J. M. Shriram, R. A. Patil, T. S. Ghangale*, N. Sumitha, B. N. Ralebhat and P. A. Kate
}

Vasantrao Naik Marathwada Krishi Vidyapeeth, Parbhani (MS), India

*Corresponding author

\begin{tabular}{|l|}
\hline Ke y w o r d s \\
$\begin{array}{l}\text { Rootstocks, Growth } \\
\text { regulators, Growth } \\
\text { characters }\end{array}$ \\
\hline Article Info \\
\hline $\begin{array}{l}\text { Accepted: } \\
\text { 07 January } 2021 \\
\text { Available Online: } \\
\text { 10 February } 2021\end{array}$ \\
\hline
\end{tabular}

\section{A B S T R A C T}

The present investigation was undertaken at the Instructional-cum-Research Farm, College of Agriculture, Osmanabad, Dist. Osmanabad. The experiment was laid out in Factorial Randomized Block Design (FRBD) with two factors first factor was Rootstock Variety with five level viz. Dogrigde, Salt Creek, 1613 C, $110 \mathrm{R}$ and $99 \mathrm{R}$ and second factor was plant growth regulators four level (IAA- 100ppm, IAA- 200 ppm, IBA- 100 ppm and IBA$200 \mathrm{ppm})$. The cuttings of rootstocks were treated with plant growth regulators as per treatments. The observations on growth character of grape rootstock were recorded. The results revealed that all the growth characters of grape rootstock cuttings i.e. minimum days required for sprouting $(15.80 \mathrm{~d})$ and maximum sprouting \% (69.59\%), leaf area $\left(144.00 \mathrm{~cm}^{2}\right)$ and survival $\%(69.60 \%)$ were noted under the treatment $\mathrm{T}_{9}$. The significantly maximum number of sprouted cuttings (8.33) was noted under the treatment $\mathrm{T}_{10}$. The significantly maximum number of leaves per cutting (14.13) was recorded in treatment $\mathrm{T}_{2}$. The significantly maximum length of shoot after 30 days $(4.34 \mathrm{~cm})$ and length of shoot after 90 days $(10.54 \mathrm{~cm})$ was recorded in treatment $\mathrm{T}_{15}$. So, it can be concluded from the study that, for better growth performance of rootstocks the plant growth regulator (IAA) with concentration (100ppm and $200 \mathrm{ppm}$ ) is suitable.

\section{Introduction}

Grape (Vitis venifera L.) is one of the most delicious, refreshing fruit. Considering the advantages, demands for the crop is increasing day by day and is gaining much importance in the fruit industry. The grape vine is generally propagated by vegetative method such as hard wood cutting. Vegetative propagation is preferred because the plants propagated by this method produce fruits early, give more yield and true to type and quality fruit every year. The treatments of cuttings with plant growth regulators play an important role in regeneration of plants from cuttings. Reports on the systematic investigation on the propagation of grape from cuttings are very scanty. Therefore, it is felt necessary to undertake the study on propagation of grape vines by using different concentration of plant growth regulators for quicker multiplication in nursery.

Grapes are one of the commercially important fruit crops in India and are cultivated on approximately $138^{\prime} 000$ hectares, with an 
annual production of 22920.1,000 (MT). It is well known for its delicacy and is a good source of minerals like calcium, phosphorous, iron and vitamins. Grape is cultivated on an area of 1,38,000 hectares worldwide with an annual production of 2920.1'000 (MT). Spain, France, Italy and USA being the leading grape producing countries in the world (Anon., 2018). Maharashtra, Tamil Nadu, Karnataka, Punjab and Andhra Pradesh are the major grape growing states of India (Anon., 2018). In Maharashtra highest Area and Production of grape is 105.50'000 ha and Production 2286.44 metric tons (Anon., 2018).

Grapes are commercially propagated through hardwood cuttings (Weaver, 1976). Cuttings are made from shoots that are one season old and have three to four nodes. They are planted in the media to induce rooting before being transplanted in the field. Dogridge is one of the commercially important rootstock and is known for its drought tolerance. It is a more vigorous variety and Thompson Seedless grafted onto this rootstock is known to produce more vegetative growth at the cost of reproductive growth, thus reducing the yield per unit area. The rooting ability of rootstocks varies with the species, IBA concentration, and the biochemical composition of the mother vines (Satish et al., 2007).

Plant growth regulators are the organic chemical compounds, which modify or regulate physiological processes in an appreciable measure in the plants when used in small concentrations. They are readily absorbed and move rapidly through the tissues, when applied to different parts of the plant. They are specific in action. The plant naturally produces plant hormones or phytohormones and they move from the site of production to the site of action. The most commonly employed growth regulators are Indole Butyric Acid (IBA) and Indole Acetic
Acid (IAA) and Gibberellic Acid $\left(\mathrm{GA}_{3}\right)$ is used for stem elongation (Hartman, 1997). Auxins were the group of growth regulators to be discovered in the late 1800's by Charles Darwin. Auxins play a major role in stem elongation and apical dominance. One of the most well-known uses of auxin is for the rooting of cutting for plant propagation. Shoot tips of many plant species when dipped or coated with small amount of auxin develop roots more quickly and higher numbers.

\section{Materials and Methods}

The experiment was conducted under polyhouse of College of Agriculture, Osmanabad during 2019 - 2020. The experiment was laid out in factorial randomized block design (FRBD) with three replication. The experiment comprised of twenty treatment combinations of five root stocks namely Dogrigde, Salt Creek, 1613 C, $110 \mathrm{R}$ and $99 \mathrm{R}$ and two growth regulators namely IndoleBceticAcid (IAA) and Indole Butyric Acid (IBA) with two concentration so each plant growth regulators were used i.e. IAA at $100 \mathrm{ppm}$ and $200 \mathrm{ppm}$ and IAA at 100 ppm and $200 \mathrm{ppm}$. The hardwood cuttings of grapes rootstock. The average length and diameter of the cuttings used for rooting was $25-30$ and $0.87 \mathrm{~cm}$, respectively. The basal end of all the cuttings was given a slanting cut to expose maximum absorbing surface for effective rooting. The required quantities of growth regulators were prepared through stock solution with their different concentrations i.e. (IAA 100ppm, 200 ppm and IBA 100 ppm, 200 ppm). Forty polybags of were taken for each treatment in each replication. Four small holes were on each bag, for proper drainage. The basal $3-4 \mathrm{~cm}$ portion of hard wood cuttings was treated with solutions (IAA and IBA) by prolong dip method for $24 \mathrm{hr}$ and were allowed to dry for 15 minutes and then planted in polythene bags filled with sand and cocopeat mixture as per 
treatments. Forty cuttings were used per treatment per replication.

\section{Results and Discussion}

\section{Days required for sprouting}

Results (Table 1) represent that days required for sprouting of rootstock cuttings ranged from 15.80 to 20.06 DAP. Minimum duration 15.80 DAP was obtained in $1613 \mathrm{C}$ rootstock treated with 100 ppm IAA and Maximum duration 20.06 DAP was obtained in110 R rootstock treated with $200 \mathrm{ppm}$ IAA. The data on days required for sprouting was significantly under the all treatment. This might have better utilization of stored carbohydrates, nitrogen in the cutting with the auxins like IAA and IBA application enhanced the auxin concentration in the cell and increased the cell division on quick callus formation in the cutting earlier completion of physiological processes in rooting and sprouting of cuttings as stated by Mewar et al., (2018) in fig. similar results were reported by Patil et al., (2000) in grape and Chauhan et al., (1971) in plum.

\section{Number of sprouted cutting}

Results (Table 1) represent that number of sprouted cuttings of rootstock. The maximum number of sprouted cutting (8.33) was obtained in $1613 \mathrm{C}$ rootstock treated with 200 ppm IAA and minimum number of sprouted cutting (6.33) was obtained in $99 \mathrm{R}$ rootstock treated with $200 \mathrm{ppm}$ IBA. The data on number of sprouting cutting was significantly under the all treatment. This might have clear from the above result that the synthesis of auxins likes IAA and IBA plays important role in induce the more number of sprouted cuttings. If the profuse rooting which occurs due to the exogenous application of those growth regulators results in more induce the food material. This stored food material food material is responsible for early sprouting of bud of the cuttings thus increase more number of shoots as stated by Patil et al., (2001) in grape. Similar results were reported by Singh and Singh (1973), Mewar et al., (2018) in fig. Damar et al., (2014) in pomegranate.

\section{Sprouting percentage (\%)}

Results (Table 1) represent that sprouting percentage $(\%)$ of rootstock cuttings. The maximum sprouting percentage $(69.60 \%)$ was obtained in $1613 \mathrm{C}$ rootstock treated with 100 ppm IAA and Minimum sprouting percentage $(52.77 \%)$ was obtained in $110 \mathrm{R}$ rootstock treated with $200 \mathrm{ppm}$ IBA. The data on sprouting percentage was significantly under the all treatment. This might have clear from the above result that the increase in sprouting percentage of cutting. The number of sprouts and sprout might be due to better utilization of stored carbohydrates, nitrogen and other factors with the help of growth regulators. Application of the auxins like IAA and IBA might have caused hydrolysis and translocation of carbohydrates and nitrogeneous substances at the base of cuttings and resulted in accelerated cell division and cell elongation as stated by Abhinav et al., (2016) and Uzunoglu and Gokbayrak (2018) in grape. Similar results were reported by Iqbal et al., (1999) in apple, Singh et al., (2009), Seiar (2017) in pomegranate.

\section{Survival percentage $(\%)$}

Results (Table 1) reveal that maximum survival percentage of rootstock cuttings $(69.60 \%)$ were recorded in rootstock of 1613 $\mathrm{C}$ treated with $100 \mathrm{ppm}$ IAA and the other hand minimum survival percentage $(46.22 \%)$ was recorded in rootstock of $110 \mathrm{R}$ treated with 100 ppm IBA. The data on survival percentage was significantly under the all treatment. This might have clear from the 
above result that the increases in the survival percentage of cutting. Application of the auxins like IAA and IBA might have increased length, maximum number of primary roots and early sprouting resulted in more thickness of the roots, perhaps the ability of regenerating further new fibrous roots from main roots, which probably absorb more nutrients and water from the soil under low transpirational losses. The effect of auxins might be due to the slow translocation property or slow destruction of auxins by auxin destroying enzyme system and early formation of roots and more utilization of reserved food materials of the treated cuttings as stated by Ghosh et al., (2017) in phalsa. Similar results were reported by Singh and Bahadur (2015) and Singh et al., (2015) in phalsa, Debnath and Maiti (1990) in Guava, Patil et al., (2001) in grape.

\section{Number of leaves/ cutting}

Results (Table 1) represent that number of leaves/ cuttings of rootstock. The maximum number of leaves cutting (14.13) was obtained in Dogrigde rootstock treated with 200 ppm IAA and minimum number of leaves/ cutting (9.73) was obtained in rootstock treated with 100 ppm IAA. The data on number of leaves/ cutting was significantly under the all treatment. This might have clear from the above result that the synthesis of auxins likes IAA and IBA plays important role in induce the more number of leaves. This attributed to increased cell division and elongation at higher IAA and IBA concentrations and its possible reason for increased activation of shoot growth which probably increased the number of nodes that lead to development of more number of leaves as stated by Rolaniya et al., (2018) in grape. Similar results were reported by Abhinav et al., (2016) in grape, patil et al., (2001) in grape, Botaty and Saleh (2018) in grape.

\section{Number of bud/ cutting}

Results (Table 1) represent that number of bud/ cuttings of rootstock. The maximum number of bud/ cutting (1.66) was obtained in $1613 \mathrm{C}$ rootstock treated with $100 \mathrm{ppm}$ IBA and minimum number of bud/ cutting (1.33) was obtained in rootstock treated with 200 ppm IBA. The data on number of bud/ cutting was significantly under the all treatment. This might have clear from the above result that the increases in number of bud per cutting might be due to better utilization Of stored carbohydrates, nitrogen and other factors with the help of growth regulators. Application of the auxins like IAA and IBA might have caused hydrolysis and translocation of carbohydrates and nitrogeneous substances at the base of cuttings and resulted in accelerated cell division and cell elongation as stated Rolaniya et al., (2018) in grape. Similar results were reported by Alia et al., (2000), Borah and Das (2000) in fig, Rawat et al., (2004) in grape, Akhtar et al., (2015) in rose.

\section{Leaf area $\left(\mathrm{cm}^{2)}\right.$}

Results (Table 1) represent that leaf area of rootstock. The maximum leaf area (144.00) was obtained in $1613 \mathrm{C}$ rootstock treated with 100 ppm IAA and minimum leaf area (81.09) was obtained in rootstock treated with 100 ppm IBA. The data on number of bud/ cutting was significantly under the all treatment. The relative humidity and optimum light intensity which are the important factor in the development of leaf coupled with auxin content the synthesis of more carbohydrates in the leaves which might have resulted in elongation of leaves through cell division and cell elongation as stated by Ghosh et al., (2017) in Phalsa. Similar results were reported by Baghel and Saraswat (1989) in pomegranate, Abhinav et al., (2016) in grape. 
Table.1 Response of rootstock variety and growth regulators to growth parameters of hardwood cuttings of grape rootstock

\begin{tabular}{|c|c|c|c|c|c|c|c|}
\hline Treatment & $\begin{array}{l}\text { Days } \\
\text { required } \\
\text { for } \\
\text { sprouting }\end{array}$ & $\begin{array}{c}\text { No. of } \\
\text { sprouted } \\
\text { cutting }\end{array}$ & $\begin{array}{c}\text { Sprouting } \\
\%\end{array}$ & $\begin{array}{c}\text { Survival } \\
\%\end{array}$ & $\begin{array}{l}\text { No. of } \\
\text { leaves/ } \\
\text { cutting }\end{array}$ & $\begin{array}{c}\text { No. of } \\
\text { bud/ } \\
\text { cutting }\end{array}$ & $\begin{array}{c}\text { Leaf area } \\
\left(\mathrm{cm}^{2}\right)\end{array}$ \\
\hline \multicolumn{8}{|l|}{$\begin{array}{l}\text { A) Rootstock } \\
\text { variety }\end{array}$} \\
\hline$V_{1}$ & 17.18 & 6.91 & 55.04 & 51.48 & 11.96 & 1.59 & 110.34 \\
\hline$V_{2}$ & 18.20 & 7.58 & 60.31 & 56.51 & 10.81 & 1.53 & 98.49 \\
\hline$V_{3}$ & 17.26 & 7.66 & 63.74 & 58.99 & 12.18 & 1.46 & 114.26 \\
\hline$V_{4}$ & 18.76 & 6.83 & 56.93 & 49.29 & 12.55 & 1.50 & 114.34 \\
\hline V5 & 19.43 & 7.41 & 60.41 & 53.87 & 12.98 & 1.51 & 116.01 \\
\hline S. Em \pm & 0.23 & 0.14 & 0.68 & 1.20 & 0.37 & 0.02 & 2.55 \\
\hline C.D. at 5\% level & 0.66 & 0.42 & 1.96 & 3.46 & 1.07 & 0.07 & 7.34 \\
\hline \multicolumn{8}{|l|}{$\begin{array}{l}\text { B) Plant growth } \\
\text { regulators }\end{array}$} \\
\hline $\mathbf{G}_{1}$ & 17.77 & 7.13 & 59.39 & 54.79 & 11.90 & 1.53 & 116.66 \\
\hline $\mathbf{G}_{2}$ & 18.68 & 7.66 & 61.74 & 56.11 & 12.50 & 1.44 & 115.74 \\
\hline $\mathbf{G}_{3}$ & 17.97 & 7.26 & 59.29 & 53.48 & 11.34 & 1.58 & 99.00 \\
\hline $\mathbf{G}_{4}$ & 18.25 & 7.06 & 56.73 & 51.73 & 12.64 & 1.50 & 111.38 \\
\hline S. Em \pm & 0.20 & 0.13 & 0.61 & 1.07 & 0.33 & 0.02 & 2.28 \\
\hline C.D. at $5 \%$ level & 0.59 & 0.38 & 1.75 & 3.09 & 0.96 & 0.06 & 6.57 \\
\hline \multicolumn{8}{|l|}{$\begin{array}{l}\text { C) Interaction } \\
(\mathbf{V} \times \mathbf{G})\end{array}$} \\
\hline $\mathbf{V}_{1} G_{1}$ & 17.06 & 7.00 & 55.15 & 52.22 & 9.73 & 1.50 & 88.70 \\
\hline $\mathbf{V}_{1} \mathbf{G}_{2}$ & 16.80 & 7.33 & 58.72 & 55.83 & 14.13 & 1.66 & 128.56 \\
\hline$V_{1} G_{3}$ & 17.20 & 6.66 & 53.17 & 46.66 & 10.00 & 1.66 & 96.82 \\
\hline$V_{1} G_{4}$ & 17.66 & 6.66 & 53.13 & 51.24 & 14.00 & 1.53 & 127.31 \\
\hline $\mathbf{V}_{2} \mathbf{G}_{1}$ & 17.53 & 7.00 & 55.55 & 53.32 & 10.13 & 1.66 & 106.00 \\
\hline $\mathbf{V}_{2} \mathbf{G}_{2}$ & 18.26 & 8.00 & 63.88 & 61.14 & 11.80 & 1.40 & 112.49 \\
\hline $\mathbf{V}_{2} \mathbf{G}_{3}$ & 18.53 & 8.00 & 63.49 & 58.88 & 11.26 & 1.40 & 81.09 \\
\hline $\mathbf{V}_{2} \mathbf{G}_{4}$ & 18.46 & 7.33 & 58.33 & 52.71 & 10.06 & 1.66 & 94.33 \\
\hline $\mathbf{V}_{3} \mathbf{G}_{1}$ & 15.80 & 7.66 & 69.59 & 69.60 & 13.53 & 1.60 & 144.00 \\
\hline $\mathbf{V}_{\mathbf{3}} \mathbf{G}_{\mathbf{2}}$ & 18.86 & 8.33 & 63.88 & 57.22 & 11.86 & 1.26 & 105.51 \\
\hline $\mathbf{V}_{3} \mathbf{G}_{3}$ & 16.73 & 7.33 & 60.39 & 54.99 & 9.80 & 1.66 & 86.60 \\
\hline $\mathbf{V}_{3} \mathbf{G}_{4}$ & 17.66 & 7.33 & 61.11 & 54.14 & 13.53 & 1.33 & 121.03 \\
\hline $\mathbf{V}_{4} \mathbf{G}_{1}$ & 19.20 & 7.33 & 61.11 & 49.26 & 13.20 & 1.40 & 126.85 \\
\hline $\mathbf{V}_{4} \mathbf{G}_{2}$ & 20.06 & 7.33 & 61.09 & 52.81 & 11.80 & 1.53 & 109.61 \\
\hline $\mathbf{V}_{4} \mathbf{G}_{3}$ & 18.13 & 6.33 & 52.77 & 46.22 & 12.67 & 1.66 & 116.06 \\
\hline $\mathbf{V}_{4} \mathbf{G}_{4}$ & 17.66 & 6.33 & 52.77 & 48.88 & 12.53 & 1.40 & 104.84 \\
\hline $\mathbf{V}_{5} \mathbf{G}_{1}$ & 19.26 & 6.66 & 55.55 & 49.59 & 12.93 & 1.60 & 117.68 \\
\hline $\mathbf{V}_{5} \mathbf{G}_{2}$ & 19.40 & 7.33 & 61.09 & 53.55 & 12.93 & 1.33 & 122.51 \\
\hline $\mathbf{V}_{5} \mathbf{G}_{3}$ & 19.26 & 8.00 & 66.66 & 60.66 & 13.00 & 1.53 & 114.45 \\
\hline $\mathbf{V}_{5} \mathbf{G}_{4}$ & 19.80 & 7.66 & 58.33 & 51.70 & 13.06 & 1.60 & 109.41 \\
\hline S. Em \pm & 0.46 & 0.29 & 1.36 & 2.41 & 0.75 & 0.05 & 5.11 \\
\hline C.D. at $5 \%$ level & 1.33 & 0.85 & 3.93 & 6.92 & 2.15 & 0.15 & 14.69 \\
\hline
\end{tabular}


Table.2 Response of rootstock variety and growth regulators to growth parameters of hardwood cuttings of grape rootstock

\begin{tabular}{|c|c|c|c|c|c|c|c|c|c|}
\hline \multirow[t]{2}{*}{ Treatment } & \multicolumn{4}{|c|}{ Length of shoot (days) } & \multirow{2}{*}{$\begin{array}{c}\text { Fresh } \\
\text { wt. of } \\
\text { shoot } \\
\text { (g) }\end{array}$} & \multirow{2}{*}{$\begin{array}{c}\text { Dry } \\
\text { wt. of } \\
\text { shoot } \\
(\mathrm{g})\end{array}$} & \multirow{2}{*}{$\begin{array}{c}\text { Root: } \\
\text { shoot } \\
\text { ratio on } \\
\text { dry wt. } \\
\text { basis }\end{array}$} & \multirow{2}{*}{$\begin{array}{l}\text { Root: } \\
\text { shoot } \\
\text { ratio on } \\
\text { Fresh wt. } \\
\text { basis }\end{array}$} & \multirow{2}{*}{$\begin{array}{l}\text { Root: } \\
\text { shoot } \\
\text { ratio on } \\
\text { dry wt. } \\
\text { basis }\end{array}$} \\
\hline & 30 & 60 & 90 & 120 & & & & & \\
\hline \multicolumn{10}{|c|}{ A) Rootstock variety } \\
\hline$V_{1}$ & 2.52 & 8.02 & 8.84 & 10.49 & 1.58 & 0.71 & 1.05 & 0.92 & 1.65 \\
\hline $\mathbf{V}_{2}$ & 1.90 & 5.22 & 7.07 & 8.36 & 1.54 & 0.66 & 0.97 & 0.93 & 2.26 \\
\hline $\mathbf{V}_{3}$ & 2.50 & 5.90 & 7.14 & 9.30 & 1.65 & 0.78 & 0.80 & 0.91 & 2.25 \\
\hline $\mathbf{V}_{4}$ & 3.91 & 7.66 & 9.02 & 10.78 & 1.61 & 0.78 & 0.68 & 0.86 & 1.61 \\
\hline V5 & 2.64 & 6.38 & 8.58 & 10.69 & 1.62 & 0.76 & 0.77 & 0.84 & 1.82 \\
\hline S. Em \pm & 0.11 & 0.21 & 0.22 & 0.25 & $\mathbf{0 . 0 2}$ & $\mathbf{0 . 0 2}$ & 0.01 & 0.01 & $\mathbf{0 . 0 3}$ \\
\hline C.D. at $5 \%$ level & 0.32 & 0.62 & 0.64 & 0.72 & 0.05 & 0.06 & 0.05 & 0.05 & 0.09 \\
\hline \multicolumn{10}{|l|}{$\begin{array}{l}\text { B) Plant growth } \\
\text { regulators }\end{array}$} \\
\hline $\mathbf{G}_{1}$ & 2.53 & 6.49 & 8.62 & 10.50 & 1.64 & 0.80 & 0.82 & 0.93 & 1.94 \\
\hline $\mathbf{G}_{\mathbf{2}}$ & 2.85 & 6.66 & 8.00 & 10.06 & 1.55 & 0.64 & 0.96 & 0.87 & 1.84 \\
\hline $\mathbf{G}_{\mathbf{3}}$ & 2.88 & 7.21 & 8.49 & 9.54 & 1.61 & 0.77 & 0.80 & 0.87 & 1.96 \\
\hline $\mathbf{G}_{4}$ & 2.52 & 6.18 & 7.41 & 9.60 & 1.59 & 0.75 & 0.82 & 0.89 & 1.93 \\
\hline S. Em \pm & 0.10 & 0.19 & 0.20 & 0.22 & 0.01 & 0.02 & 0.01 & 0.01 & 0.03 \\
\hline C.D. at 5\% level & 0.29 & 0.55 & 0.58 & 0.64 & 0.05 & 0.05 & 0.04 & 0.04 & 0.08 \\
\hline \multicolumn{10}{|c|}{ C) Interaction $(\mathbf{V} \times \mathbf{G})$} \\
\hline $\mathbf{V}_{1} \mathbf{G}_{1}$ & 2.86 & 8.42 & 10.19 & 11.40 & 1.56 & 0.64 & 1.22 & 1.06 & 1.63 \\
\hline$V_{1} G_{2}$ & 2.68 & 6.96 & 9.66 & 11.89 & 1.68 & 0.75 & 1.03 & 0.59 & 1.39 \\
\hline $\mathbf{V}_{1} \mathbf{G}_{3}$ & 2.62 & 10.50 & 7.75 & 9.64 & 1.50 & 0.76 & 1.01 & 1.02 & 1.89 \\
\hline$V_{1} G_{4}$ & 1.92 & 6.16 & 7.75 & 9.02 & 1.58 & 0.68 & 0.93 & 0.99 & 1.68 \\
\hline $\mathbf{V}_{2} \mathbf{G}_{1}$ & 2.15 & 5.98 & 7.81 & 9.51 & 1.71 & 0.75 & 0.86 & 0.80 & 2.09 \\
\hline $\mathbf{V}_{2} \mathbf{G}_{2}$ & 2.10 & 5.23 & 6.51 & 7.67 & 1.46 & 0.55 & 1.30 & 1.02 & 2.64 \\
\hline $\mathbf{V}_{2} \mathbf{G}_{3}$ & 1.76 & 4.46 & 7.31 & 7.47 & 1.56 & 0.67 & 0.71 & 0.80 & 2.39 \\
\hline $\mathbf{V}_{2} \mathbf{G}_{4}$ & 1.60 & 5.22 & 6.66 & 8.79 & 1.42 & 0.66 & 1.02 & 1.11 & 1.91 \\
\hline $\mathbf{V}_{\mathbf{3}} \mathbf{G}_{\mathbf{1}}$ & 2.86 & 5.70 & 7.50 & 9.08 & 1.69 & 0.86 & 0.56 & 0.95 & 2.49 \\
\hline $\mathbf{V}_{3} \mathbf{G}_{2}$ & 1.74 & 5.24 & 5.86 & 8.83 & 1.41 & 0.54 & 1.26 & 1.08 & 1.92 \\
\hline $\mathbf{V}_{\mathbf{3}} \mathbf{G}_{\mathbf{3}}$ & 2.89 & 6.17 & 8.37 & 9.16 & 1.80 & 0.86 & 0.59 & 0.72 & 2.26 \\
\hline$V_{3} G_{4}$ & 2.50 & 6.51 & 6.84 & 10.14 & 1.71 & 0.87 & 0.79 & 0.89 & 2.32 \\
\hline $\mathbf{V}_{4} \mathbf{G}_{1}$ & 3.04 & 6.66 & 8.60 & 9.56 & 1.63 & 0.89 & 0.74 & 0.95 & 1.64 \\
\hline $\mathbf{V}_{\mathbf{4}} \mathbf{G}_{2}$ & 4.11 & 8.60 & 8.99 & 11.44 & 1.61 & 0.67 & 0.69 & 0.94 & 1.63 \\
\hline $\mathbf{V}_{4} \mathbf{G}_{3}$ & 4.34 & 8.16 & 10.54 & 11.31 & 1.62 & 0.88 & 0.70 & 0.82 & 1.44 \\
\hline$V_{4} G_{4}$ & 4.17 & 7.21 & 7.94 & 10.81 & 1.60 & 0.69 & 0.60 & 0.73 & 1.75 \\
\hline $\mathbf{V}_{5} \mathbf{G}_{1}$ & 1.74 & 5.69 & 9.02 & 12.94 & 1.63 & 0.85 & 0.74 & 0.92 & 1.83 \\
\hline $\mathbf{V}_{5} \mathbf{G}_{2}$ & 3.63 & 7.30 & 8.97 & 10.46 & 1.60 & 0.68 & 0.55 & 0.74 & 1.62 \\
\hline$V_{5} G_{3}$ & 2.78 & 6.72 & 8.48 & 10.11 & 1.58 & 0.67 & 1.00 & 0.98 & 1.80 \\
\hline $\mathbf{V}_{5} \mathbf{G}_{4}$ & 2.44 & 5.79 & 7.86 & 9.26 & 1.66 & 0.84 & 0.78 & 0.74 & 2.02 \\
\hline S. Em \pm & 0.22 & 0.19 & 0.45 & 0.50 & 0.04 & 0.04 & 0.03 & 0.03 & 0.06 \\
\hline C.D. at 5\% level & 0.65 & 0.55 & 1.29 & 1.44 & 0.11 & 0.12 & 0.10 & 0.10 & 0.19 \\
\hline
\end{tabular}




\section{Length of shoot (at 30, 60, 90, \& 120 days)}

Results (Table 2) represent that length of shoot after 30 days of rootstock. The maximum length of shoot after 30 days (4.34 d) was obtained in $110 \mathrm{R}$ rootstock treated with $100 \mathrm{ppm}$ IBA and minimum length of shoot after 30 days $(1.60 \mathrm{~d})$ was obtained in salt creek rootstock treated with $200 \mathrm{ppm}$ IBA. The data on length of shoot after 30 days was significantly under the all treatment. The results (Table 2) represent that length of shoot after 60 days of rootstock. The maximum length of shoot after 60 days (8.60 d) was obtained in $110 \mathrm{R}$ rootstock treated with 200 ppm IAA and minimum length of shoot after 60 days $(5.22 \mathrm{~d})$ was obtained in salt creek rootstock treated with $200 \mathrm{ppm}$ IBA. The data on length of shoot after 60 days was significantly under the all treatment. The results (Table 2) represent that length of shoot after 90 days of rootstock. The maximum length of shoot after 90 days (10.54 d) was obtained in $110 \mathrm{R}$ rootstock treated with $100 \mathrm{ppm}$ IBA and minimum length of shoot after 90 days $(6.51 \mathrm{~d})$ was obtained in salt creek rootstock treated with $200 \mathrm{ppm}$ IAA. The data on length of shoot after 90 days was significantly under the all treatment. The results (Table 2) represent that length of shoot after 120 days of rootstock. The maximum length of shoot after 120 days (12.94d) was obtained in $99 \mathrm{R}$ rootstock treated with $100 \mathrm{ppm}$ IAA and minimum length of shoot after 120 days (7.47 d) was obtained in salt creek rootstock treated with $100 \mathrm{ppm}$ IBA. The data on length of shoot after 120 days was significantly under the all treatment. This might have high auxin concentrations, it has an inhibitory effect on growth of buds, effect that can be caused by apical dominance. The increasing of auxin concentration, shoot length and number of leafs also increased. He was reported that the probable reason for the increase in length of shoots may be the better utilization of carbohydrates, nitrogen and other nutrients, which has been aided by growth regulators. Shoot growth also increases the number of nodes in the shoot. It might have resulted in elongation of leaves through cell division and cell elongation as stated by Abhinav et al., (2016) in grape. Similar results were reported by Iqbal et al., (1999) in apple.

\section{Fresh weight of shoot $(\mathrm{g})$}

Results (Table 2) represent that fresh wt. of shoot of rootstock. The maximum fresh wt. of shoot $(1.80 \mathrm{~g})$ was obtained in $1613 \mathrm{C}$ rootstock treated with $100 \mathrm{ppm}$ IBA and minimum fresh wt. of shoot $(1.55 \mathrm{~g})$ was obtained in rootstock $1613 \mathrm{C}$ treated with 200 ppm IAA. The data on fresh wt. of shoot was significantly under the all treatment. This might have clear from the above result that the increases in the Fresh weight of shoot of cuttings. Application of the auxins like IAA and IBA produced more number of sprouts, leaves, increased leaf area, leaf chlorophyll content, more starch, total sugar and $\mathrm{C} / \mathrm{N}$ ratio. It might have resulted in elongation of leaves through cell division and cell elongation as stated by Ghosh et al., (2017) in phalsa. Similar results were reported by Purohit and Shekarappa (1985) in pomegranate, Mehta et al., (2016) in pear. Shukla and Bist (1994) in pear, Singh and Tomar (2015) in Phalsa

\section{Dry weight of shoot (g)}

Results (Table 2) represent that dry wt. of shoot of rootstock. The maximum dry wt. of shoot $(0.89 \mathrm{~g})$ was obtained in $110 \mathrm{R}$ rootstock treated with $100 \mathrm{ppm}$ IBA and minimum dry wt. of shoot $(0.54 \mathrm{~g})$ was obtained in rootstock $1613 \mathrm{C}$ treated with 200 ppm IAA. The data on fresh wt. of shoot was significantly under the all treatment. This might have clear from the above result that the increases in the Dry weight of shoot of 
cuttings. Application of the auxins like IAA and IBA produced more number of sprouts, leaves, increased leaf area, leaf chlorophyll content, more starch, total sugar and $\mathrm{C} / \mathrm{N}$ ratio. It might have resulted in elongation of leaves through cell division and cell elongation as stated by Ghosh et al., (2017) in phalsa. Similar results were reported by Purohit and Shekarappa (1985) in pomegranate, Mehta et al., (2016) in pear, Shukla and Bist (1994) in pear, Singh and Tomar (2015) in Phalsa.

\section{Root: shoot ratio on dry weight basis}

Results (Table 2) represent that Root: shoot ratio on dry weight basis of rootstock. The maximum Root: shoot ratio on dry weight basis (1.30) was obtained in salt creek rootstock treated with 200 ppm IAA and minimum Root: shoot ratio on dry weight basis (0.54) was obtained in rootstock $99 \mathrm{R}$ treated with 200 ppm IAA. The data on Root: shoot ratio on dry wt. basis was significantly under the all treatment. This might have clear from the above result that the increases in the Root: shoot ratio on Dry weight basis of the cuttings. The application of auxins like IAA and IBA concentration activated the synthesis of carbohydrates in the shoots which might have resulted elongation of leaves through cell division and cell elongation as stated by Ghosh et al., (2017) in phalsa.

\section{Root: shoot ratio on fresh weight basis}

Results (Table 2) represent that Root: shoot ratio on fresh weight basis of rootstock. The maximum Root: shoot ratio on fresh weight basis (1.11) was obtained in salt creek rootstock treated with $200 \mathrm{ppm}$ IAA and minimum Root: shoot ratio on fresh weight basis (1.39) was obtained in Dogrigde rootstock treated with 200 ppm IAA. The data on Root: shoot ratio on fresh weight basis was significantly under the all treatment. This might have clear from the above resulted that the increases in the Root: shoot ratio on fresh weight basis of the cuttings. The application of auxins like IAA and IBA concentration activated the synthesis of carbohydrates in the shoots which might have resulted elongation of leaves through cell division and cell elongation as stated by Ghosh et al., (2017) in phalsa.

\section{Root: shoot ratio on Length basis}

Results (Table 2) represent that Root: shoot ratio on length basis of rootstock. The maximum Root: shoot ratio on length basis (2.64) was obtained in salt creek rootstock treated with 200 ppm IAA and minimum Root: shoot ratio on length basis (0.59) was obtained in Dogrigde rootstock treated with 200 ppm IAA. The data on Root: shoot ratio on length basis was significantly under the all treatment. This might have clear from the above resulted that the increases in the Root: shoot ratio on fresh wt. basis of the cuttings. The application of auxins like IAA and IBA concentration activated the synthesis of carbohydrates in the shoots which might have resulted elongation of leaves through cell division and cell elongation as stated by Ghosh et al., (2017) in phalsa.

From the above discussion it may be concluded that various level of Rootstock variety and plant growth regulators level had growth character studied under this experiment. Results are larger sprouting and survival percentage in rootstock cutting within short period of time. For better growth of rootstock the plant growth regulators (IAA) with concentration (100 ppm and $200 \mathrm{ppm}$ ) is suitable.

\section{References}

Anonymous, 2018 .National Horticulture Board. nhb.gov.in. 
Abhinav., Burman, R. N., Kanpure, S. R., Anjanawe, A., Haldar, R. P., Patel., Singh, T. and Yadav, S. K. 2016. Effect of biofertilizers and growth regulators on rooting and growth of hard wood cutting of grapevine (Vitis venifera L.) cv. Thompson seedless Res. Environ. Life Sci. 9(12) 1522-1525.

Akhtar.,Gulzar., Jaskani., Jafar, M., Sajjad, Y.and Akram, A. 2016. Effect of Antioxidants, Amino Acids and Plant Growth Regulators on in vitro Propagation of Rosa centifolia. Iran J Biotech. 14(1):e115.

Baghel, B. S. and Saraswat, B. K. 1989. Effect of different rooting media on rooting and growth of hardwood and semi hard wood cuttings of pomegranate (Punica granatum L.).Indian J Hort.; 46:458-462.

Borah, W. S. and Das, K. K. 2000. Effect of Indole butyric acid on rooting of cuttings in Pomegranate.J. Punjab Agri. Uni., 29(3):350-353.27.

Botaty, S. and Saleh, M. M. S. 2018. Effect of Some Natural Substances on Grape Cuttings Rooting Middle East Journal of Agriculture Research ISSN 20774605 Volume: 07 Pages: 1702-1709.21.

Chauhan, K. S. and Reddy, R. S. 1971. Effect of growth regulators and mist on rooting in stem cutting of plum (Prunus domestica L.). Indian J Hort.; 25:22923122.

Damar, D., Barholia, A. K., Lekhi, R. and Haldar, A. 2014.Effect of growth regulators and biofertilizers on survival of pomegranate (Punica granatum L.) Stem cuttings Plant Archives. Vol. 14 No. 347-350.23.

Debnath, G. C. and Maiti, S. C. 1990. Effect of growth regulators on rooting of softwood cuttings of guava (Psidium guajava L.) under mist. Haryana $J$ Hort Sci.; 19:79-85.24.

Ghosh, A., Dey, K., Mani, A., Bauri, F. K and
Mishra, D. K. 2017.Efficacy of different levels of IBA and NAA on rooting of Phalsa (Grewia asiatica L.) cuttings. International Journal of Chemical Studies 5(6): 567-571.

Hartmann, H. T., Kester, D. E., Davis, F. T. and Geneve, R. L. Plant Propagation: Principles and Practices, Prentice Hall, Upper Saddle River, NJ, USA, 6th edition, 1997.

Iqbal.,Mohmmad., Subham, F., Ghafoor, A., Waseem, K. and Jilani, M. S. 1999. Effect of different concentration of IBA on plant survival of apple cuttings. Pakistan Journal of Biological Sciences, 4: 1314-1316.26.

Mehta, N. S., Bhatt, S .S., Kumar, J.. Kotiyal, A. and Dimri, D. C.2016. Effect of IBA on Vegetative Growth and Multiplication rate in Stem Cuttings of Pear Rootstocks Hort flora Research Spectrum Vol. 5, Issue 3; 242-245.

Mewar, D., Nautiyal, M. C. and Singh, K. K. 2018.Response of Various IBA Concentrations to Wild Fig (Ficus palmate Forsk.) Cuttings under Controlled Conditions. International Journal of Advanced Scientific Research and Management, Special Issue I, Jan ISSN: 2455-6378.13.

Patil, V. N., Chauhan, P.S., Shivankar, R. S., Vilhekar, S. H. and Waghmare, V. S. 2001.Effect of Plant Growth Regulators on Survival and Vegetative Growth of Grapevine Cuttings.Agric.Sci, Digest. 21 (2): 97.99.14.

Patil, V. N., Chauhan, P. S., Panchbhai, D. M., Shivankar, R. S. and Tannirwar, A. V. 2000.Effect of different growth regulators on rooting of hardwood cuttings of some commercial grape varieties.J Soils Crops. 10(2): 295297.12.

Purohit, A. G. and Shekarappa, K. E. 1985.Effect of type of cutting and indolebutyric acid on rooting of 
hardwood cuttings of pomegranate (Punica granatum L.). Indian J Hort.; 42:30-36.11.

Rawat, T. S., Singh, J. and Verma, V. 2004.Response of grape cuttings (Vitis vinifera L.) to plant growth regulators. Sci.Horti. For 9:61-65. 10.

Rolaniya, M. K., Khushbu, M. B. and Sarvanan, S. 2018. Effect of plant growth regulators (IIA, IBA, GA3) on rooting of hardwood cutting of Grape (Vitis venifera L.) Thompson seedless. Journal of Pharmacognosy and Phytochemistry, SP1:398-400.

Satish, S., Mohana, D. C., Raghavendra, M. P., Raveesha, K. A., 2007. Antifungal activity of some plant extracts against important seed borne pathogens of Aspergillus sp. Journal of Agricultural Technolo.

Seiar, A.Y. 2001. Effect of growth regulators on rooting of cuttings in pomegranate (Punica granatum L.) cv. 'Bhagwa'. J. Hortl. Sci. Vol. 11(2): 156-160.9.

Shukla, G. S. and Bist, L. D. 1994. Studies on efficacy of IBA and NAA on clonal propagation by cutting in low chilling pear rootstock. Indian J Hort. 51(4): 351-357.4.

Singh, A. K. and Bahadur, V. 2015. Effect of
NAA and IBA on rooting and establishment of hard wood cutting in Phalsa (Grewia subinaequalis L.).The Allahabad Farmer. LXX(2): 199-201.

Singh, B., Singh, S. and Singh, G. 2009. Influence of planting time and IBA on rooting and growth of pomegranate (Punica granatum L.) cv 'Ganesh' cuttings. ISHS. Acta. Hort., 890, Int. sym. of pomegranate.

Singh, K. K. and Tomar, Y. K. 2015.Effect of planting time and indole butyric acid levels on rooting of woody cuttings of phalsa (Grewia asiatica L.). Hort Flora Research Spectrum, 4(1): 39-43.6.

Singh, R., and Singh, P., 1973. Punjab Hort. J.13 (2-3): 166-170.7.

Singh, V. P., Mishra, D. S., Mishra, N. K. and Ratna, R. 2015. Effect of growing season, PGRs and rooting media on survival of hard wood stem cuttings of lemon (Citrus limon Burm.) cv. Pant lemon-1.Hort FloraRes Spectrum 4: 347-350.8.

Uzunoglu, O. and Gokbayrak, Z. 2018. Influence of IAA, 28-homobrassinolide and 24-epibrassinolide on Adventitious Rooting in Grapevine. Araştırma Makalesi/ Research Article 6 (1): 23-30 ISSN: 2147-8384 / e-ISSN: 2564-6826.

\section{How to cite this article:}

Shriram, J. M., R. A. Patil, T. S. Ghangale, N. Sumitha, B. N. Ralebhat and Kate, P. A. 2021. Effect of Plant Growth Regulators on Growth of Grape Rootstock. Int.J.Curr.Microbiol.App.Sci. 10(02): 728-737. doi: https://doi.org/10.20546/ijcmas.2021.1002.087 